\title{
Biological models for phytochemical research: from cell to human organism
}

\author{
Alicja Mortensen ${ }^{1}$, Ilona K. Sorensen ${ }^{1}$, Colin Wilde ${ }^{2}$, Stefania Dragoni ${ }^{3}$, Dana Mullerová ${ }^{4}$, \\ Olivier Toussaint ${ }^{5}$, Zdeněk Zloch ${ }^{4}$, Giampietro Sgaragli ${ }^{4}$ and Jaroslava Ovesná ${ }^{6} *$

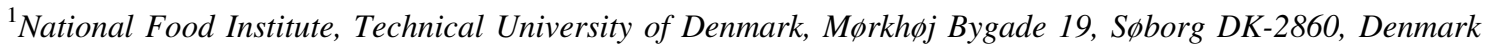 \\ ${ }^{2}$ AvantiCell Science Ltd, GibbsYard Building, Auchincruive, Ayr KA6 5HW, Scotland, UK \\ ${ }^{3}$ Department of Biomedical Sciences, University of Siena, Banchi di Sotto, Siena 55 - 53110, Italy \\ ${ }^{4}$ Institute of Health Promotion, Medical faculty in Pilsen, Charles University, Lidicka 4, Pilsen 301 66, Czech Republic \\ ${ }^{5}$ Department of Biology, Unit of Cellular Biochemistry and Biology, University of Namur (FUNDP), Namur 5000, France \\ ${ }^{6}$ Crop Research Institute, Drnovská 507, Prague 6-Ruzyne 161 06, Czech Republic
}

\begin{abstract}
Nutrigenomics represents a shift of nutrition research from epidemiology and physiology to molecular biology and genetics. Nutrigenomics seeks to understand nutrition influences on homeostasis, the mechanism of genetic predispositions for diseases, to identify the genes influencing risk of diet related diseases. This review presents some in vitro models applicable in nutrigenomic studies, and discuses the use of animal models, their advantages and limitations and relevance for human situation. In vitro and in vivo models are suitable for performance of DNA microarrays, proteomic and transcriptomic analyses. In vitro models (intracellular organelles and suborganellar compartments, cell cultures, or tissue samples/cultures) give insight in metabolic pathways and responses to test stimuli on cellular and molecular levels. Animal models allow evaluation of the biological significance of the effects recorded in vitro and testing of the hypothesis on how a specific factor affects specific species under specific circumstances. Therefore, the evaluation of the data in relation to human organism should be done carefully, considering the species differences. The use of in vitro and in vivo models is likely to continue as the effects of nutrition on health and disease cannot be fully explained without understanding of nutrients action at nuclear level and their role in the intra- and intercellular signal transduction. Through advances in cell and molecular biology (including genomic and proteomic), the use of these models should become more predictively accurate. However, this predictive value relies on an underpinning knowledge of the advantages and limitations of the model in nutrigenomic research as in other fields of biomedical research.
\end{abstract}

Nutrigenomics: In vitro models: Animal models: Human studies

It is widely recognized nowadays that human health is influenced by genetic and environmental factors, and that nutrition is of fundamental importance. Increasing incidence of so called "lifestyle diseases" like obesity, type 2 diabetes, cardiovascular disease (CVD) or cancer is recognized to be related to Western-style diet. Several reports indicate that a diet rich in vegetables and fruits and low in fat may protect against these diseases ${ }^{(1-3)}$. In the last two decades nutritionists have become increasingly aware of the significance of genenutrient interactions, and their possible use as tools to improve the health of the individual. Thus, the application of nutrigenomic analysis in nutrition represents an important paradigm shift in nutrition research, from epidemiology and physiology to molecular biology and genetics. Nutrigenomics (nutritional genomics) represents the junction between the health, diet, and genomics, and is focused upon genetic polymorphism and the interaction of the genome with diet ${ }^{(4)}$. Nutrients are judged as potential signals, which influence cellular sensor systems to modify gene expression and subsequently metabolite production. Nutrigenomics seeks to understand how nutrition influences homeostasis and to identify the genes influencing risk of diet-related diseases as well as to understand the mechanism of the genetic predispositions for the diseases. For example, a nutrigenomics approach offers promise in modulating the risk of diseases of ageing because of the effects of certain nutrients on gene expression, through both epigenetic mechanisms or modification of transcription factors. Therefore it might be the first step to a personalised nutrition health policy.

It is accepted that the genetic material of each cell is not a rigid but a dynamic structure changing in response to various stimuli including food ${ }^{(5)}$. The knowledge of the genome and its expression in living organisms, coupled with the tools of molecular biology create the prospect of examining the health benefits of dietary phytochemicals on cellular level in in vitro model systems and scrutinizing the most potent compounds in in vivo model systems (animal models of cancer, atherosclerosis, diabetes) and in human subjects.

Abbreviations: CVD, cardiovascular disease; ER, endoplasmic reticulum; FAE, follicle associated epithelium; LDLR, low-density lipoprotein receptor; , 3-D cultures, 3-dimensional cultures; WHHL, Watanabe heritable hyperlipidemic; CYP7A1, cholesterol 7-hydroxylase; LDL-C, LDL cholesterol.

* Corresponding author: J. Ovesná, fax +42023302 22 86, email ovesna@vurv.cz 
In applying these various approaches there is an over-arching expectation that research is ethically-acceptable, and that researchers apply the three "Rs" (reduction, replacement, refinement $)^{(6)}$ with respect to the use of animals in biological research.

Every human possesses a unique genotype reacting in its own way upon food contituents ${ }^{(7,8)}$. Clearly, it is impossible for practical reasons to study response to food constituents for each individual separately, and so the interaction of nutrition with mammalian gene expression is routinely studied in model systems, whose cellular and molecular biology can be defined in qualitative and (preferably) quantitative terms. Depending on the question to be elucidated, a model can consist of cell structures, cell cultures, tissue sample/culture (in vitro models) or of group of living organisms like animals or humans (in vivo models). Both in vitro and in vivo model systems are suitable for performance of DNA microarrays, proteomics and transcriptomics analyses.

This review presents some of the in vitro and in vivo models, which are applicable for studies of biological effects of phytochemicals on gene expression, cellular metabolism, activity of enzymes metabolizing xenobiotics, clinical biomarkers and end points of lifestyle diseases (e.g. cancer, atherosclerosis), and discusses the use of animal models, their advantages, limitations and relevance to the human situation.

\section{In vitro models}

In vitro models are based on the use of intracellular organelles and suborganellar compartments, cell cultures, or tissue slice/ organoid bioassays. Studies in such model systems give insight into responses to the tested factors on a cellular level. This insight and its overall value must, however, be tempered by recognition of the limitations of the model system, not least whether it can be considered of physiological relevance or indicative of the biology of a multi-organellar environment in vivo. In this section we review the advantages and limitations of a range of in vitro systems in ascending degree of sophistication.

Microsomes, a small inclusion of ribosomes and fragments of the endoplasmic reticulum (ER) serves as example of a subcellular in vitro model. Microsomes are broadly used to investigate the metabolising actions of the phase I and phase II xenobiotic-metabolising enzymes, which typically include the cytochrome P450 isoforms. Testing of nutritional factors in this cell-free system can indicate likely patterns of metabolism, but is not necessarily indicative of the fate of the test molecule in a more complex environment, not least one in which cellular uptake is a significant factor.

Yeast, as an eukaryotic organism, represents a simple but useful model genome of which is fully sequenced and individual metabolic pathways are well know. At present several precisely defined mutant and transformed lines exist. The advantage of this model system is that growth conditions can be fully controlled and response upon stimuli easily measured. Therefore yeast has been successfully used e.g. as a model system for screening of phytochemicals for estrogenic activity ${ }^{(9)}$

Cell lines of various origin, some of which may be clonally derived from single cells have some attraction for the study of gene-nutrient interactions. With careful control of cell passaging and culture conditions, the availability of a homogeneous cell population can offer advantages in terms of reproducibility of response and experiment replication. The practical convenience of an easily-handled and renewable test platform is also suited to medium to high-throughput, should screening of large number of test molecules be required. On the other hand, cell lines may have been in culture for extended periods (months, years or decades), and through de-differentiation and/or genetic damage can bear little or no resemblance to their tissue of origin.

One example of a cell line frequently used in nutritional modelling is the Caco-2 cell line. Caco-2 is derived from human colorectal carcinoma but it retains many of the morphological features typical for normal human enterocytes ${ }^{(10)}$. Caco- 2 cells have been extensively studied and there is a considerable literature concerning their characteristics ${ }^{(11-18)}$. Caco-2 cells may serve as a model system for predicting intestinal absorption of drugs or nutraceuticals ${ }^{(19-20)}$ and are also used for evaluating of dietary constituents as well as food additives, contaminants, toxicants and oxidants and for testing of possible anti-cancer/ protective effects of phenolic compounds ${ }^{(21)}$. The advantage of this test system is that the cells are of human origin, and that experiments can be carried out over a relatively long period permitting the reversibility of any effects to be assessed $^{(22)}$. The Caco- 2 cell line is also the basis of the so-called follicle associated epithelium (FAE), consisting of co-culturing of Caco-2 cells with human B lymphoma Raji cells to induce Caco-2 cells differentiation into M cells ${ }^{(23)}$. The FAE model may be useful for study of potential toxicological effects on the human gut epithelium of different nanoparticles and their potential capacity to cross the intestinal epithelium.

A second example of a cell line in widespread use for nutritional/metabolic studies is the human hepatoma cell line $\mathrm{HepG} 2^{(24)}$ and its sub-clones. HepG2 continues to find application in the evaluation of a range of nutritional factors, including spice constituents ${ }^{(25)}$, soybean derivatives ${ }^{(26)}$ and tuber essential oils ${ }^{(27)}$, as well as providing a means of evaluating medicinal materials from natural sources ${ }^{(28,29)}$. However, whilst a valuable tool, the HepG2 cell line does not necessarily reflect faithfully the performance of test materials in vivo. Cytochrome P450 enzyme activities and Phase II metabolic functions are relatively low, and a recent study demonstrated the failure of HepG2 cultures to detect compounds with known toxicity in primary hepatocytes or in vivo ${ }^{(30)}$.

Recognition of the limitation of cell lines as models of metabolic performance in vivo is increasingly encouraging investment in the production of fresh or cryopreserved primary cell cultures prepared from animal or human tissues. For instance, cultured endothelial cells and macrophages can be applied as in vitro model for studying flavonoids in redox-dependent gene expression ${ }^{(31)}$. The technology for enzymic tissue digestion and cell isolation is well-established for many animal tissues, including liver and intestine, from a range of species $^{(32,34)}$, and with it the potential to cryopreserve cells with retention of xenobiotic-metabolising activity (see, for example, Stevenson et al. ${ }^{(35)}$ ). Increasing access, with appropriate ethical permission, to human tissue is similarly enabling the isolation and use of human cells which can, under appropriate conditions, retain a differentiated phenotype in culture for days and even weeks ${ }^{(36,37)}$. The benefit of such a primary cellculture approach in nutritional research was demonstrated as much as 30 years ago in cultured skin fibroblasts, whose use 
led to discovery of the low-density lipoprotein receptor (LDLR) on the cell surface, and facilitated understanding of endogenous pathways in cholesterol metabolism ${ }^{(38)}$.

It has long been recognised that use of freshly isolated cells is not by itself sufficient to confer physiological relevance on data obtained using these cultures. Primary cell performance is dependent on their microenvironment and their potential for paracrine interaction with neighbouring cells of the same or different cell type. One way to reproduce these microenvironmental influences in vitro, not least for nutrigenomic research, is to avoid cell dissociation through the use of organ slices or tissue explants. Organ slices represent a multicellular threedimensional in vitro model, which possesses the biologicallyrelevant structural and functional features of in vivo tissues through the presence of various cell types in an architectural organization that supports both cell-cell and cell-extracellular matrix interactions. Organ slice methodology is readily adaptable to various organs and various species. The availability of human tissue for organ slice studies augments the utility of this model, and provides an important bridge between animalderived data and the human situation. Precision-cut tissue slices are increasingly being used in toxicology ${ }^{(39,40)}$, to evaluate the toxicity of chemicals ${ }^{(41-43)}$, to evaluate the genotoxic and antigenotoxic potential of chemicals ${ }^{(44,45)}$, to unravel the metabolic pathways of xenobiotics ${ }^{(46)}$, to study the regulation of enzyme systems such as the cytochromes $\mathrm{P} 450^{(47)}$, to investigate the hepatic uptake of drugs ${ }^{(48)}$, activation of signalling pathways $^{(49)}$ and to determine chemically-induced apoptosis ${ }^{(50)}$. This broad spectrum of potential applications for precision-cut tissue slices in nutrigenomic research is likely to promote their use in future nutrigenomic research.

In many cases, the demonstrable metabolic performance of tissue slices will outweigh their inherent disadvantage of short functional lifespan and unsuitability for medium to large-scale analysis. In other circumstances, where treatment periods of more than a few hours are required, or volume and throughput of samples are important, technology development has focused on the creation in cell culture of conditions that elicit in vivo cellular responses. At its simplest, this involves the use of biological substrata such as collagen or reconstituted basement membrane for cell attachment ${ }^{(51)}$ or through co-culture with helper cells, or both ${ }^{(52)}$. More recently, biocompatible substrata have offered the possibility of creating architecturally-sophisticated 3-dimensional cell cultures. For study of transport phenomena this may involve the use of a biocompatible membrane, suitably coated with collagen or other extracellular matrix components, onto which the cells of choice are seeded. With this approach primary cultures of epithelial cells can become polarised, displaying distinctive basal and apical surfaces (the former forming the substratum anchorage) and demonstrating the vectorial transport characteristics of an epithelial monolayer. One example of such a system utilises mammary epithelial cells to recreate the lactating epithelium, allowing study of the transport of xenobiotics from the bloodstream into milk (C Wilde; unpublished).

The adaptation of technology aimed principally at tissue regeneration is, in addition, progressively creating 3-dimensional, biocompatible cell scaffolds in which cells can be seeded, grown and encouraged to reproduce the functions of their tissue of origin. This biomaterials technology can take the form of fibrous scaffolds spun in 3 dimensions, and may also incorporate fibre coatings that promote, for example, cell attachment or particular cell functions. Such technology has, for example, been applied to enhance cytochrome P450 activity in primary hepatocyte cultures ${ }^{(53)}$. Indeed, for hepatocytes alone, numerous other approaches to the creation of 3-D cultures are currently under development, based variously on hydrogels ${ }^{(54)}$, poly-lactic acid ${ }^{(55)}$, alginates ${ }^{(56)}$ or chitosan ${ }^{(57)}$ amongst many other materials.

Combination of biomaterials technology with stem cell science is opening up new opportunities for tissue regeneration, and with it a further in vitro option for cell-based analysis through the generation of differentiated cell types from stem cell lineages. With this approach, scaffold composition and architecture can, for example, direct the maturation of hepatocyte progenitor cell lines, with realisation of cytochrome P450 activities ${ }^{(58)}$. This approach has the considerable attraction of a renewable source of normal human cells with consistent performance, albeit with the caveat that extensive research and development is still required to define the soluble and fixed-scaffold cues that elicit a stable, differentiated phenotype ${ }^{(59,60)}$.

While in vitro studies give insight into responses at a cellular level, they are not able to provide definitive information on how the studied factor may affect the organism as a whole. Thus, the biological significance of an effect at the gene level observed in vitro should be further assessed in in vivo test(s) involving whole organisms, where exposure to a nutritional factor for instance dietary phytochemical is evaluated systemically through application of metabolomics, and pharmacokinetics such that gene-nutrient interactions of the test substance are demonstrably the aggregate of primary action at an organellar level and any secondary response due to inter-organellar cross-talk.

\section{Animals in nutritional research}

To bridge the gap between in vitro test systems and the whole organism, and to overcome the obvious constraints of human clinical studies, animal studies are widely applied in nutrition research. Animal studies can be performed in a relatively short time, enabling chronic study, potentially from in uteroexposure to death, and also research into inter-generational effects. Such pre-clinical studies, which may measure validated biomarkers of nutritional response, can be supported by post mortem examination of end-points, and further investigations on molecular level on gene expression patterns in sampled tissues. The influence of environmental factors on the results is minimised by standardization of laboratory conditions and the use of the subjects (organisms) with known genetic and health status, so called "defined animals"(61).

\section{Relevance of animal studies}

Nutrigenomics provide powerful approaches to investigate the relationship between dietary factors and genes, providing insight into how test compounds affect gene-expression patterns (transcriptome), organisation of the chromatin (epigenome), protein expression paterns, including post-translational modifications (proteome), as well as metabolite profile (metabolome). In this regard, laboratory animals are used as complex biological instruments to obtain knowledge on 
gene-nutrient interaction, whilst always recognising that extrapolation to human biology must be done with caution and recognition of sometimes-fundamental species differences. While recognising that phenomena studied in one species can sometimes be extrapolated to another ${ }^{(62)}$, and recognising that present knowledge of human biochemistry, physiology, endocrinology and pharmacology relies fundamentally on studies in animal models ${ }^{(63)}$, and that several advances in nutrigenomics were made using murine animal models ${ }^{(64)}$, it is important to stress, that animal studies including nutrigenomic research are not inherently predictive of the human situation. Animal studies can neither confirm nor refute hypotheses about human physiology or pathology; human clinical investigation is the only way to test such hypotheses.

The purpose of animal studies is to test hypothesis on how the specific factor affects the specific species under specific circumstances. Their value is speeding up the process of discovery by generation of ideas or suggesting hypotheses that might be relevant to humans, assistance in predicting effects in humans, and providing support for particular conclusions reached in the population studies. The differences in biological characteristics (e.g. anatomy, physiology, metabolic rate) between animals and man should be kept in mind while studying qualitative questions devoted to identification of the diet component responsible for a specific function in the body, or quantitative questions concerning a dose of a diet component necessary to cause the specific reaction in the body. In this regard a comparative biology continues to be a useful tool for choosing an appropriate animal model.

\section{Animal models}

A widely accepted scientific definition of an animal model is as a living organism in which normative biology or behaviour can be studied, or in which a spontaneous or induced pathological process can be investigated, and in which the phenomenon in one or more respects resembles the same phenomenon in humans ${ }^{(65)}$.

Based on this definition, animal models can be categorised in five groups: (1) normative, (2) spontaneous models in which the phenomenon under investigation occurs spontaneously e.g. $\mathrm{Apc}^{\mathrm{Min}}$ mice a model of human adenomatous poliposis coli $^{(66)}$, or a Watanabe Heritable Hyperlipidemic (WHHL) rabbit a model of human familiar hypercholesterolemia ${ }^{(67)}$, (3) experimental models in which the phenomenon is induced either chemically e.g., 1,2-dimethylhydrazine dihydrochloride or azoxymethane induced colon cancer in rats, or surgically e.g. uraemia induced by nephrotectomy, or by a genetic manipulation e.g. TG.NK mice with MMTV/C-neu transgene as a model of breast cancer ${ }^{(68)}$, (4) negative models in which the phenomenon never occurs/is suppressed either as consequence of normative physiology e.g. dog in atherosclerosis research, or due to genetic manipulation e.g. mice lacking the $5100 A 4(m t s 1)$ gene have suppressed tumour development and lack of metastases ${ }^{(69)}$ and (5) orphan models where a disease is first recognised and described in an animal species, after which a human counterpart may emerge ${ }^{(70)}$.

As an example of application of normative animal model to study biological effects of phytochemicals an investigation of influence of isoflavone intake on mammary gland morphogenesis and gene expression profile in the juvenile mammary gland of mice can be given ${ }^{(71)}$. A study of soy isoflavones effect on gene expression of endothelial nitric oxide synthase in cerebral arteries in Watanabe heritable hyperlipidemic rabbits ${ }^{(72)}$ is an example of application of a spontaneous model of human disease (familial hypercholesterolemia) to investigate health beneficial effects of phytochemicals. Similarly studies of effect of lignans or soy isoflavone on intestinal neoplasia in $A p c^{\text {Min }}$ mice $^{(73,74)}$ are examples of application of a spontaneous model, while investigations of cancer-preventing effect of soy and/or isoflavones in rats induced by dimethylbenz[a]anthracene ${ }^{(75)}$, or DMBA ${ }^{(76,77)}$ or in transgenic TG.NK mice ${ }^{(78)}$ illustrate application of so called experimental models to study cancer-preventive potential of phytochemicals.

\section{Choice of the animal model}

The decision to use an animal model in nutritional research will be informed, first, by the non-availability of ethically more acceptable in vitro alternatives. Thereafter, the choice of model will depend on their validity with respect to the nature of phenomenon under study and its expression in the biology of the chosen species. An additional consideration will be the practical aspects of the experimental procedure, husbandry and economic considerations. All these factors are routinely considered within legislative frameworks (which vary by country and institution), which ensure sound ethical practice.

When using animal models it is necessary to recognize their predictive validity (performance in the animal study predicts performance in real (non-experimental) conditions), face validity (phenomenological analogy with the modelled condition) and construct validity (the model has a sound theoretical rationale).

\section{Biology of the chosen species}

In considering the biology of the chosen species, it is essential that characterization of the biological system is sufficient to allow sound interpretation of the results. Therefore the chosen species should have defined genetic characteristics. The use of outbred and inbred strains should be considered as both have their advantages and limitations. In general outbred strains are recognized to represent populations, which are more likely to mimic the genetic diversity in human populations. The use of inbred strains is believed to minimalize the inter-individual variation in the response to a studied factor allowing smaller experimental groups and with attraction for mechanistic studies.

The anatomy, biochemistry and physiology should be close to those of man with regard to the dietary requirements and function of digestive system (Table 1). The differences in metabolic rates between the laboratory animal species and between the chosen species and humans should be considered. The latter is important in choice of the dose of test compound for animal dietary interventions ${ }^{(79,80)}$, and an appropriate animal versus human compensation factor should be applied (Table 2).

The type of experimental diet and feeding regimens (ad libitum versus diet restriction or pair feeding) should also be considered ${ }^{(81)}$. Factors to consider include the choice between the standard fixed open-formula diets based on natural plant ingredients and therefore containing diverse 
Table 1. Selected variables and characteristics relevant when choosing a laboratory species as a model in nutrition research

\begin{tabular}{|c|c|c|c|c|c|}
\hline $\begin{array}{l}\text { Species (body weight) } \\
\text { Digestive system }\end{array}$ & $\begin{array}{l}\text { Mouse }(20-40 \mathrm{~g}) \\
\text { Omnivore }\end{array}$ & $\begin{array}{l}\text { Rat }(150-300 \mathrm{~g}) \\
\text { Omnivore }\end{array}$ & $\begin{array}{l}\text { Pig }(60 \mathrm{~kg}) \\
\text { Omnivore }\end{array}$ & $\begin{array}{l}\text { Hamster } \\
\text { Herbivore }\end{array}$ & $\begin{array}{c}\text { Man }(60-80 \mathrm{~kg}) \\
\text { Omnivore }\end{array}$ \\
\hline \multicolumn{6}{|l|}{ Dietary requirement } \\
\hline Fat intake $(\mathrm{g})$ & 0.3 & $0.5 \mathrm{~g}$ & $64 \mathrm{~g}$ & & $129 \mathrm{~g}$ \\
\hline Polyunsaturated/S & 1.85 & 1.85 & 1.85 & 1.85 & 0.4 \\
\hline Fat energy $\%$ & 11 & 11 & 10 & 11 & 44 \\
\hline Protein energy \% & 18 & 18 & 25 & 18 & 14 \\
\hline Carbohydrate energy \% & 70 & 70 & 65 & 70 & 42 \\
\hline Volume of blood sampling $(\mathrm{ml})^{\mathrm{a}}$ & 0.13 & $0.8-1.3$ & 250 & 0.5 & $450^{\mathrm{b}}$ \\
\hline Method of blood sampling & Easy & Easy & Difficult & Easy & - \\
\hline Acquiring and maintaining & Cheap/easy & Cheap/easy & $\begin{array}{l}\text { Relativelyc } \\
\text { easy/cheap }\end{array}$ & Cheap/easy & - \\
\hline $\begin{array}{l}\text { Availability of commercial } \\
\text { kits for examination of } \\
\text { gene expression }\end{array}$ & Available & Available & $\begin{array}{l}\text { In process of } \\
\text { development } \\
\text { and validation }\end{array}$ & $\begin{array}{l}\text { In process of } \\
\text { development } \\
\text { and validation }\end{array}$ & Available \\
\hline
\end{tabular}

${ }^{a}$ The presented values are a guidance for repeated blood sampling at weekly intervals. The volume of a sample corresponds to approximately $7.5 \%$ of total blood volume, and to $0.5 \%$ of body weight.

${ }^{b}$ The normal quantum drawn from blood donors.

${ }^{c}$ The cost of a pig exceeds that of laboratory rodent. Pigs need more space and special housing facilities, and large quantities of feed and of test compounds compared to

laboratory rodents. Thus availability of facilities for housing and expenses to experimental feed/test compounds should be considered.

${ }^{*}$ Rats do not have a bile bladder.

phytochemicals like phytoestrogens, isoflavones and lignans, respectively ${ }^{(82,83)}$, or purified semi-synthetic or synthetic diets. These diets are composed of a refined, invariant, and restricted set of ingredients, which offer less variable and more easily controlled experimental conditions. Additionally, the use of purified or synthetic diets instead of natural ingredient chows, gives more precise control over the metabolizable energy, dietary composition of nutrient, and provides better repeatable experimental conditions ${ }^{(84)}$. On the other hand, casein in purified semi-synthetic diet aggravates hypercholesterolemia in rabbit models of atherosclerosis ${ }^{(85)}$ and can therefore mask potential hypocholesterolemic effects of phytochemicals in a rabbit model of atherosclerosis or naturally occurring phytochemicals in standard laboratory chow may be confounding factors in studies of anti-atherogenic effects of phytochemicals ${ }^{(86)}$ or in studies of other biological effects of test phytochemicals. Switching from standard laboratory chow to purified diet (and vice versa) changes the gut flora, which may lead to altered endogenous vitamin synthesis. Furthermore, the occurrence of common contaminants in natural-ingredient non-purified (standard) diets such as heavy metals (e.g. $\mathrm{Pb}$ and $\mathrm{As}$ ), $\mathrm{N}$-nitrosamines, residua of pesticides and antioxidants (BHA and BHT) may serve to confound experiment outcomes ${ }^{(87)}$.
An optimal diet for laboratory animals should have adequate concentrations of all the nutrients for growth and maintenance without substantial excess of high energy and growth-enhancing nutrients such as fat and protein. However, depending on the aim of the study, it is an open question if the experimental diet should be a standard for the chosen species or should mimic the human Western diet with regard to fat, fibre, and calcium content ${ }^{(88)}$. Feeding a Western style diet instead of a standard chow diet to a rodent model of cancer can exacerbate cancer development ${ }^{(89)}$. While choosing the feeding regimens it is worthwhile remembering that diet restriction may modify the responses to (phyto)chemicals, and that the practice is labour-intensive.

Another potential source of experimental variation can arise from homeostatic compensatory reactions, which can result in low precision and scattering of results and even misinterpretations $^{(61)}$.

In conclusion, whilst nutrigenomic studies in animal models have value in predicting the human situation, their use must be justified on sound biological criteria, on practical grounds (with respect to housing, feeding and intervention for sample collection) and from an ethical perspective (availability of alternatives, and predictive value). Ultimately,

Table 2. Mouse dosage compensation factor - examples

\begin{tabular}{|c|c|c|}
\hline Factor and value & Basis/comments/examples & Reference \\
\hline Human to mouse equivalency factor: 9.0 & Body surface area and body weight & The US EPA Handbook \\
\hline $\begin{array}{l}\text { Conversion factor from human } \\
\text { to mouse from dietary concentrations } \\
\text { to dose per kg body weight (bw): } 7 \cdot 5\end{array}$ & $\begin{array}{l}\text { Food intake, body weight e.g. dose } \\
\text { of a compound at dietary concentration } \\
1 \mathrm{ppm}(=1 \mathrm{mg} / \mathrm{kg} \text { diet) corresponds to } \\
0.02 \mathrm{mg} / \mathrm{kg} \mathrm{bw} \text { for a human and to } \\
0.15 \mathrm{mg} / \mathrm{kg} \mathrm{bw} \text { for a mouse }\end{array}$ & Modified from OECD, 2000 \\
\hline $\begin{array}{l}\text { Energy requirement ratio } \\
\text { (per kg bw): } 11.4\end{array}$ & $\begin{array}{l}\text { Human }(60 \mathrm{~kg}) \text { energy intake is } \\
2000 \mathrm{kcal} / \mathrm{day} \approx 33 \mathrm{kcal} / \mathrm{kg} \text { bw. } \\
\text { Mouse }(40 \mathrm{~g}) \text { caloric intake (maintenance) } \\
\text { is } 15 \mathrm{kcal} / \mathrm{day} \approx 375 \mathrm{kcal} / \mathrm{kg} \mathrm{bw}\end{array}$ & GN Rao (personal communication) \\
\hline $\begin{array}{l}\text { Conversion factor from human to } \\
\text { mouse for anticancer agents:12.3 }\end{array}$ & Body surface, metabolism rate and body weight & Freireich et al. $1966^{(79)}$ \\
\hline
\end{tabular}


the effects observed in animal models should be demonstrated in humans.

\section{Human studies}

Human nutritional studies can be divided into intervention studies (trials), which under defined circumstances (such as clinical trials), apply nutritional intervention and measure the biological outcome (effect), and observational epidemiological studies, divided into descriptive (correlational, case reportseries, cross sectional) and analytical experimentation (casecontrol, cohort), and meta-analyses. Studies, according to study design, may be prospective or retrospective and may use epidemiological instruments to evaluate biological outcome of an identified nutritional factor or nutrition-genomic relationship.

\section{Intervention studies}

Intervention studies differentiate between double blind/(nonblinded) and randomized/(non-randomized) controlled trials. Nutritional trials in human volunteers may typically examine the biological effects of nutrient/nutrients [as e.g. glucan enriched fruit juice ${ }^{(90)}$ or polyphenols in olive oils $\left.{ }^{(91)}\right]$, or whole foodstuffs [e.g. dried cranberry juice ${ }^{(92)}$ ] or food commodities [e.g. vegetables and fruit ${ }^{(93,94)}$ ] or the effect of different, albeit sometimes imprecisely defined types of diet [e.g.Mediterranean-style ${ }^{(95)}$ or low fat dietary pattern ${ }^{(96)}$ ]. The principle of a nutrigenomic approach i.e. an investigation of whether certain nutrients have direct effects on gene expression is exemplified by a randomised controlled trial studying the effect of omega-3, omega- 6 , and omega- 9 unsaturated fatty acids on unstimulated and stimulated monocytes cytokine gene expression ${ }^{(97)}$, and by a trial of conjugated linoleic acid supplementation ${ }^{(98)}$. Another type of nutrigenomic approach may test a hypothesis that, for example, a particular gene polymorphism is more or less indicative of a biological outcome determined by special type of diet/nutrients. This type of study is represented by work on human volunteers identifying the cholesterol 7-hydroxylase (CYP7A1) gene and its role in determining the LDL-cholesterol (LDL-C) concentration response to a high-fat $\operatorname{diet}^{(99)}$.

\section{Observational epidemiological studies}

A particularly critical point in nutritional epidemiology is the ability of the epidemiological instrument to measure habitual dietary intake. Dietary-assessment instruments are used in nutritional descriptional or analytical studies. An example of a descriptive cross sectional study is the study dealing with the fruit and vegetable intakes and bone density ${ }^{(100)}$ or a population-based study on diabetes mellitus and serum carotenoids $^{(101)}$

Analytical, case-control nutritional studies are based on long-term recall of feeding history. They are especially valid for assessment of gene-environment interactions, where there is a critical demand to improve the accuracy in measurements of both genetic and nutritional factors.

Meta-analyses of observational studies try on a comprehensive, systematic bibliographic search of published medical literature to arrive at quantitative conclusions about the contribution of nutritional factors to the occurrence of disease, for example the relationship between fruit and vegetable intake and the occurrence of oral cancer ${ }^{(102)}$.

Summarizing the current knowledge and experience within the nutrition research in human studies indicates that methodological as well as heuristic limits of epidemiological (including interventional) and clinical trials have been reached. The effects of nutrition on health and disease cannot be fully explained without a more comprehensive understanding of how nutrients act at nuclear level and what role they play in the intra- and intercellular signal transduction.

\section{Concluding remarks}

Direct, definitive information on the effects of dietary factors, whether they be nutritional or non-nutritional dietary components, on human health can only be obtained through investigation in human subjects. However, the obvious ethical and practical limitations of interventionist human studies limit their applicability. Because of these limitations, intervention trials in healthy subjects and patients often provide information only on early or short-lasting biological effects of the treatment. In consequence, the duration of the intervention is usually much too short to allow study of patho-physiological end-points of interest (e.g. development of tumours or atherosclerotic lesions), and therefore disease indicators are typically measured as clinico-chemical biomarkers. Furthermore, the confounding factors of lifestyle and poor compliance of human subjects with the study protocol may influence the results obtained. Epidemiological studies can be resource-effective but time-consuming, and interpretation of the results is difficult because of the multifactorial nature of the effect. Other more technical obstacles also exist.

The limitations related to human studies are the reason for using alternative model systems in nutritional research and nutrigenetics. Well-characterized in vitro model systems give insight in metabolic pathways and responses to test stimuli on cellular and molecular levels, while studies in animal models permit evaluation of the biological significance of the effects recorded in in vitro studies. Human nutritional trials may then become justifiable, based on primary knowledge obtained from studies in vitro, animal models or observational epidemiological studies.

Nutrigenomics will promote an increased understanding of how nutrition influences metabolic pathways and homeostatic control, how this regulation is disturbed in the early phases of diet-related disease, and the extent to which individual sensitizing genotypes contribute to such diseases. Keeping in mind the limitations of human studies, the use of in vitro and in vivo models will continue and, through advances in cell and molecular biology (including genomic and proteomic), should become more predictively accurate. However, this predictive value relies on an underpinning knowledge of the advantages and limitations of the model in nutrigenomic research as in other fields of biomedical research.

\section{Acknowledgements}

The publication of this paper was made possible by the financial support of the European Co-operation in the field of Scientific 
and Technical (COST) Research Action 926 "Impact of new technologies on the health benefits and safety of bioactive plant compounds" (2004-2008) and the projects of the Czech Ministry of Education 1P05OC054 and MZe 002700602. The authors had no conflicts of interest to disclose.

\section{References}

1. Donaldson MS (2004) Nutrition and cancer: a review of the evidence for anti-cancer diet. Nutr J 3, 19, Published online 2004 October 20. doi: 10.1186/1475-2891-3-19. Available from http:/www.nutritionj.com/content/3/1/19.

2. Alonso A \& Martínez-González MA (2004) Olive oil consumption and reduced incidence of hypertension: The SUN study. Lipids 39, 1233-1238.

3. Goh SSC, Woodman OL, Pepe S, Cao AH, Quin C \& Ritchie RH (2007) The red wine antioxidant resveratrol prevents cardiomyocyte injury following ischemia-reperfusion via multiple sites and mechanisms. Antioxid Redox Signal 9, 101-113.

4. Afman L \& Müller M (2006) Nutrigenomics: from molecular nutrition to prevention of disease. J Am Diet Assoc 106, 569-576.

5. van den Veyver IB (2002) Genetic effects of methylation diets. Аппи Rev Nutr 22, 255-282.

6. de Boom MJ, Rennie AE, Buchanan-Smith HM \& Hendriksen CFM (2005) The interplay between replacement, reduction and refinement: Considerations where the three Rs interact. Anim Welf 14, 327-332.

7. Ordovacs JM \& Corella1 D (2004) Nutritional genomics. Annu Rev Genomics Hum Genet 5, 71-118.

8. Buttriss JL, Hughes J, Colette NMK \& Stanner S (2002) Antioxidants in food: a summary of the review conducted for the Food Standards Agency 2002, British Nutrition Foundation. Nutr Bull 27, 227-236.

9. Breinholt V \& Larsen JC (1998) Detection of weak estrogenic flavonoids using a recombinant yeast strain and a modified MCF7 cell proliferation assay. Chem Res Toxicol 11, 622-629.

10. Pinto M, Robine-Leon S, Appay M-D, Kedinger M, Triadou N, Dussaulx E, Lacroix B, Simon-Assmann P, Haffen K, Fogh J, Zweibaum A, et al. (1983) Enterocyte-like differentiation and polarization of the human colon carcinoma cell line Caco-2 in culture. Biol Cell 47, 323-330.

11. Brandsch M, Miyamoto Y, Ganapathy V \& Leibach FH (2004) Expression and protein kinase C-dependent regulation of peptide/ $\mathrm{H}+$ co-transport system in the Caco-2 human colon carcinoma cell line. Biochem J 299, 253-260.

12. Hidalgo IJ \& Borchardt RT (1990) Transport of bile acids in a human intestinal epithelial cell line, Caco-2. Biochim Biophys Acta 1035, 97-103.

13. Yamamoto T, Seino Y, Fukumoto H, Koh G, Yano H, Inagaki N, Yamada Y, Inoue K, Manabe T \& Imura H (1990) Overexpression of facilitative glucose transporter genes in human cancer. Biochem Biophys Res Commun 170, 223-230.

14. Hochman JH, Fix JA \& LeCluyse EL (1994) In vitro and in vivo analysis of the mechanism of absorption enhancement by palmitoylcarnitine. J Pharmacol Exp Ther 269, 813-822.

15. Grasset E, Pinto M, Dussaulx E, Zweibaum A \& Desjeux JF (1984) Epithelial properties of human colonic carcinoma cell line Caco-2: electrical parameters. Am J Physiol Cell Physiol 247, C260-C267.

16. Pinto M, Appay MD, Simonassmann P, Chevalier G, Dracopoli N, Fogh J \& Zweibaum A (1982) Enterocytic differentiation of cultured human-colon cancer-cells by replacement of glucose by galactose in the medium. Biol Cell 44, 193-196.

17. Chantret I, Barbat A, Dussaulx E, Brattain MG \& Zweibaum A (1988) Epithelial polarity, villin expression, and enterocytic differentiation of cultured human colon carcinoma cells: a survey of twenty cell lines. Cancer Res 48, 1936-1942.

18. Jumarie C \& Malo C (1991) Caco-2 cells cultured in serumfree medium as a model for the study of enterocytic differentiation in vitro. J Cell Physiol 149, 24-33.

19. Artrusson P (1990) Epithelial transport of drugs in cell culture. I: a model for studying the passive diffusion of drugs over intestinal absorptive (Caco-2) cells. J Pharm Sci 79, 476-482.

20. Trotter PJ \& Storch J (1991) Fatty acid uptake and metabolism in a human intestinal cell line (Caco-2): comparison of apical and basolateral incubation. J Lipid Res 32, 293-304.

21. Giovannini C, Straface E, Modesti D, Coni E, Cantafora A, de Vincenti M, Malorni W \& Masella R (1999) Tyrosol, the major olive oil biophenol, protects against oxidized-LDL induced injury in Caco-2 Cells. J Nutr 129, 1269-1276.

22. Anderberg EK \& Artursson P (1993) Epithelial transport of drugs in cell culture. VIII: Effects of the pharmaceutical surfactant excipient sodium dodecyl sulphate on cell membrane and tight junction permeability in human intestinal epithelial (Caco-2) cells. J Pharm Sci 82, 392-398.

23. des Rieux A, Fievez V, Théate I, Mast J, Préat V \& Schneider YJ (2007) An improved in vitro model of human intestinal follicle-associated epithelium to study nanoparticle transport by M cells. Eur J Pharm Sci 30, 380-391.

24. Aden DP, Fogel A, Plotkin S, Damjanov I \& Knowles BB (1979) Controlled synthesis of HBsAg in a differentiated human liver carcinoma-derived cell line. Nature 282, 615-616.

25. Cao J, Liu Y, Jia L, Zhou HM, Kong Y, Yang G, Jiang LP, Li QJ \& Zhong LF (2007) Curcumin induces apoptosis through mitochondrial hyperpolarization and mtDNA damage in human hepatoma G2 cells. Free Radic Biol Med 43, 968-975.

26. Carter BA, Taylor OA, Prendergast DR, Zimmerman TL, Von Furstenberg RV, Moore DD \& Karpen SJ (2007) Stigmasterol, a soy lipid-derived phytosterol, is an antagonist of the bile acid nuclear receptor FXR. Pediatr Res 62, 301-306.

27. Chung MJ, Woo Park K, Heon Kim K, Kim CT, Pill Baek J, Bang KH, Choi YM \& Lee SJ (2008) Asian plaintain (Plantago asiatica) essential oils suppress 3-hydroxy-3methyl-glutaryl-co-enzyme A reductase expression in vitro and in vivo and show hypocholesterolaemic properties in mice. Br J Nutr 99, 67-75.

28. Li LM, Weng ZY, Huang SX, Pu JX, Li SH, Huang H, Yang BB, Han Y, Xiao WL, Li ML, Han QB \& Sun HD (2007) Cytotoxic ent-Kauranoids from the medicinal plant Isodon xerophilus. J Nat Prod 70, 1295-1301.

29. Gomes A, Giri B, Kole L, Saha A, Debnath A \& Gomes A (2007) A crystalline compound (BM-ANF1) from the Indian toad (Bufo melanostictus, Schneider) skin extract, induced antiproliferation and apoptosis in leukemic and hepatoma cell line involving cell cycle proteins. Toxicon 50, 835-849.

30. Westerink WM \& Schoonen WG (2007) Cytochrome P450 enzyme levels in HepG2 cells and cryopreserved primary human hepatocytes and their induction in HegG2 cells Toxicol In Vitro 21, 1581-1591.

31. Rimbach G, Saliou C, Canali R \& Virgilli F (2001) Interaction between cultured endothelial cells and macrophages: in vitro model for studying flavonoids in redox-dependent gene expression. Methods Enzymol 335, 387-397.

32. Mashek DG \& Grummer RR (2004) Effect of conjugated linoleic acid isomers on lipid metabolism and gluconeogenesis in monolayer cultures of bovine hepatocytes. J Dairy Sci 87, 67-72.

33. Papeleu P, Vanhaecke T, Henkens T, Elaut G, Vinken M, Snykers S \& Rogiers V (2006) Isolation of rat hepatocytes. Methods Mol Biol 320, 229-237.

34. Rusu D, Loret S, Peulen O, Mainil J \& Dandrifosse G (2005) Immunochemical, biomolecular and biochemical characteris- 
ation of bovine epithelial intestinal primocultures. BMC Cell Biol 6, 42-52.

35. Stevenson DJ, Morgan C, Goldie E, Connel G \& Grant MH (2004) Cryopreservation of viable hepatocyte monolayers in cryoprotectant media with high serum content: metabolism of testosterone and kaempherol post-cryopreservation. Cryobiology 49, 97-113.

36. Baten A, Sakamoto K \& Shamsuddin AM (1992) Long term culture of normal human colonic epithelial cells in vitro. FASEB J 6, 2726-2734.

37. Pichard L, Raulet E, Fabre G, Ferrini JB, Ourlin JC \& Maurel P (2006) Human hepatocyte culture. Methods Mol Biol 320, $283-293$.

38. Goldstein JL \& Brown MS (1977) The low density lipoprotein pathway and its relation to atherosclerosis. Annu Rev Biochem 46, 897-930.

39. de Kanter R, Olinga P, de Jager MH, Merema MT, Meijer DKF \& Groothius GMM (1999) Organ slices as an in vitro test system for drug metabolism in human liver, lung and kidney. Toxicol in Vitro 13, 737-744.

40. Lerche-Langrand C \& Toutain HJ (2000) Precsion-cut liver slices: characteristics and use for in vitro pharmaco-toxicology. Toxicology 153, 221-253.

41. Miller MG, Beyer J, Hall GL, De Graffenried IA \& Adams PE (1993) Predictive value of liver slices for metabolism and toxicity in vivo: use of acetaminophen as a model hepatotoxicant. Toxicol Appl Pharmacol 122, 108-116.

42. Prince RJ, Mistry H, Wield PT, Renwick AB, Beamand JA \& Lake BG (1996) Comparison of the toxicity of allyl alcohol, coumarin and menadione in precision-cut rat, guinea-pig, cynomolgus monkey and human liver slices. Arch Toxicol 71, 107-111.

43. van de Bovenkamp M, Groothuis GMM, Draaisma AL, Merema MT, Bezuijen JI, Van Gils MJ, Meijer DKF, Friedman SL \& Olinga P (2005) Precision-cut liver slices as a new model to study toxicity-induced hepatic stellate cell activation in a physiologic milieu. Toxicol Sci 85, 632-638.

44. Baumann P, Kerdar RS, Cramer P, Feser W, Blode H, Salomon A \& Kuhnz W (1996) Use of rat and human liver slices for the detection of steroid hormone-induced DNA-adducts in vitro by means of the $32 \mathrm{P}$-postlabelling technique. Pharmacol Toxicol 78, 214-223.

45. Lake BG, Beamand JA, Tredger JM, Barton PT, Renwick AB \& Price RJ (1999) Inhibition of xenobiotic-induced genotoxicity in cultured precision-cut rat liver slices. Mutat Res 440, 91-100.

46. Ekins S (1996) Past, present, and future applications of precision-cut liver slices for in vitro xenobiotic metabolism. Drug Metabol Rev 28, 591-623.

47. Meredith C, Scott MP, Renwick AB, Price RJ \& Lake BG (2003) Studies on the induction of rat hepatic CYP1A, CYP2B, CYP3A and CYP4A subfamily form mRNAs in vivo and in vitro using precision-cut rat liver slices. Xenobiotica 33, 511-527.

48. Onderwater RC, Commandeur JN, Rooseboom M \& Vermeulen NP (2005) Uptake-toxicity relationships of a series of $\mathrm{N}$-substituted $\mathrm{N}^{\prime}$-(4-imidazole-ethyl)thiourea in precision-cut rat liver slices. Xenobiotica 35, 391-404.

49. Pfaff M, Powaga N, Akinci S, Schutz W, Banno Y, Wiegand S, Kummer W, Wess J \& Haberberger RV (2005) Activation of the SPHK/SIP signalling pathway is coupled to muscarinic receptor-dependent regulation of peripheral airways. Respiratory Research 6, 48; available at http://respiratory-research. com/content/6/1/48.

50. Moronvalle-Halley V, Sacre-Salem B, Sallez V, Labbe G \& Gautier JC (2005) Evaluation of cultured, precision-cut rat liver slices as a model. Toxicology 207, 203-214.

51. Kleinman HK, McGarvey ML, Hassall JR, Star VL, Cannon FB, Laurie GW \& Martin GR (1986) Basement membrane complexes with biological activity. Biochemistry 25, 312-318.
52. VanHaecke T \& Rogiers V (2006) Hepatocyte cultures in drug metabolism and toxicological research and testing. Methods Mol Biol 320, 209-227.

53. Chua KN, Tang YN, Quej CH, Ramakrishna S, Leong KW \& Mao HQA (2007) A dual-functional fibrous scaffold enhances P450 activity of cultured primary rat hepatocytes. Acta Biomater 3, 643-650.

54. Turner WS, Schmelzer E, McClelland R, Wauthier E, Chen W \& Reid LM (2007) Human hepatoblast phenotype maintained by hyaluronan hydrogels. J Biomed Mater B 82, 1560-1168.

55. Huang H, Hanada S, Kojima N \& Sakai Y (2006) Enhanced functional maturation of fetal porcine hepatocytes in threedimensional polu-L-lactic acid scaffolds: a culture condition suitable for engineered Liver tissues in large-scale animal studies. Cell Transplant 15, 799-809.

56. Elkiyam T, Amitay-Shaprut S, Dvir-Ginsburg M, Harel T \& Cohen S (2006) Enhancing the drug metabolism of C3A - a human hepatocyte cell line - by tissue engineering within alginate scaffolds. Tissue Eng 12, 1357-1368.

57. Li J, Pan J, Zhang L, Guo X \& Yu Y (2003) Culture of primary rat hepatocytes within porous chitosan scaffolds. J Biomed Mater Res A 67, 938-943.

58. Semino CE, Merok JR, Crane GG, Panagiotakos G \& Zhang S (2003) Functional differentiation of hepatocyte-like spheroid structures from putative liver progenitor cells in three-dimensional peptide scaffolds. Differentiation 71, 262-270.

59. Beckstead BL, Santosa DM \& Giachelli CM (2006) Mimicking cell-cell interactions at the biomaterial-cell interface for control of stem cell differentiation. J Biomed Mater Res A 79, 94-103.

60. Mei Y, Goldberg M \& Anderson D (2007) The development of high-throughput screening approaches for stem cell engineering. Curr Opin Chem Biol, Aug 14 (Epub ahead of print).

61. Öbrink KJ \& Rehbinde C (1993) The defined animal. Scand J Lab Anim Sci 20, 5-9.

62. Meyer O \& Svendsen O (2003) Animal models in pharmacology and toxicology. In Handbook of Laboratory Animal Science, (volume II), 2nd ed., pp. 11-39 [J Hau and GL van HoosierJr, editors]. CRC Press LLC.

63. Coffey DS \& Isaacs JT (1980) Requirements for an idealized animal model in prostatic cancer. In Models for Prostate Cancer, pp. 379-391 [GP Murphy, editor]. New York: Alan R Liss.

64. Mutch DM, Wahli W \& Williamson G (2005) Nutrigenomics and nutrigenetics: the emerging faces of nutrition. FASEB J 19, $1602-1616$.

65. Wessler S (1976) Introduction: What is a Model? In: Animal Models of Thrombosis and Hemorrhagic Diseases, xi-xvi. Bethesda, Md: National Institutes of Health.

66. Moser AR, Pitot HC \& Dove WF (1989) A dominant mutation that predisposes to multiple intestinal neoplasia in the mouse. Science 247, 322-324.

67. Goldstein JL, Kita T \& Brown MS (1983) Defective lipoprotein receptor and atherosclerosis. Lesson from an animal counterpart of familial hypercholesterolemia. $N$ Engl J Med 309, 288-296.

68. Muller WJ, Sinn E, Pattengale PK, Wallace R \& Leder P (1988) Single-step induction of mammary adenocarcinoma in transgenic mice bearing activated c-neu oncogene. Cell 54, $105-115$.

69. Grum-Schwesen B, Klingeholhofer J, Berg CH, El-Naaman C, Grigorian M, Lukanidin E \& Ambartsumian N (2005) Suppression of tumour development and metastasis formation in mice lacking the S100A4(mts1) gene. Cancer Res 65, 3772-3780.

70. Hau J, Andersen LLI, Rye Nielsen B \& Poulsen OM (1989) Laboratory animal models. Scand J Lab Anim Sci 16, Suppl. $1,7-9$. 
71. Thomsen AR, Almstrup K, Nielsen JE, Sørensen IK, Petersen OW, Leffers H \& Breinholt VM (2006) Estrogenic effect of soy isoflavones on mammary gland morphogenesis and gene expression profile. Toxicol Sci 93, 357-357.

72. Lund CO, Mortensen A, Nilas L, Breinholt VM, Larsen J-J \& Ottesen B (2007) Estrogen and phytoestrogens: Effect on eNOS expression and in vito vasodilation in cerebral arteries in ovariectomized Watanabe heritable hyperlipidemic rabbits. Eur J Obstet Gynecol Reprod Biol 130, 84-92.

73. van Kranen HJ, Mortensen A, Sørensen IK, van den Berg-Wijnands J, Beems R, Nurmi T, Adlercreutz \& van Kreijl CF (2003) Lignan precursors from flaxseed or rye bran do not protect against the development of intestinal neoplasia in $A p c^{\text {Min }}$ mice. Nutr Cancer 45, 203-210.

74. Sørensen IK, Kristiansen E, Mortensen A, Nicolaisen GM, Wijnands JAH, van Kranen HJ \& van Kreijl CF (1998) The effect of soy isoflavones on development of intestinal neoplasia in Apc ${ }^{\text {Min }}$ mice. Cancer Lett 130, 217-225.

75. Mukhopathyay S, Ballard BR, Mukherjee S, Kabir SM \& Das SK (2006) Beneficial effects of soy protein in the initiation and progression against dimethylbenz [a] anthracene-induced breast tumors in female rats. Mol Cell Biochem 290, 169-176.

76. Day JK, Besch-Williford C, McMann TR, Hufford MG, Lubahn DB \& MacDonald RS (2001) Dietary genistein increased DMBA-induced mammary adenocarcinoma in wild-type, but not ER alpha KO, mice. Nutr Res 39, 226-232.

77. Rowlands JC, HeL, Hakkak R, Ronis MJ \& Badger TM (2001) Soy and whey proteins downregulate DMBA-induced liver and mammary gland CYP1 expression in female rats. J Nutr 131, 3281-3287.

78. Thomsen AR, Mortensen A, Breinholt VM, Lindecrona RH, Penalvo JL \& Sørensen IK (2005) Influence of Prevastein, an isoflavone-rich soy product, on mammary gland development and tumorigenesis in Tg.NK (MMTV/c-neu) mice. Nutr Cancer 52, 176-188.

79. Freireich EJ, Gehan EA, Rall DP, Schmidt LH \& Skipper HE (1966) Quantitative comparison of toxicity of anticancer agents in mouse, rat, hamster, dog, monkey, and man. Cancer Chemother Rep 50, 219-244.

80. Hau J \& Poulsen OM (1988) Doses of laboratory animals based on metabolic rate. Scand J Lab Anim Sci 15, 81-83.

81. Rao GN (1988) Rodent diets for carcinogenesis studies. J Nutr 118, 929-931.

82. Thigpen JE, Li L-A, Richter CB, Lebetkin EH \& Jameson CW (1987) The mouse bioassay for detection of estrogenic activity in rodent diets: II.Comparative estrogenic activity of purified, certified and standard open and closed formula rodent diets. Lab Anim Sci 37, 602-605.

83. Degen GH, Janning P, Diel P \& Bolt HM (2002) Estrogenic isoflavones in rodent diets. Tox Letters 128, 145-157.

84. Ritskes Hoitinga M (2001) The need for defined diets and refined feeding methods. Scand J Anim Sci 28, 51-54.

85. Hausner EA, Schlingmann KL, Chen WH, Gillies PG, Kieras CJ, Ross PE \& van Pelt CS (1995) Hepaticand adrenal changes in rabbits associated with hyperlipidemia caused by a semi-synthetic diet. Lab Anim Sci 45, 663-670.

86. Frederiksen H, Mortensen A, Schrøder M, Frandsen H, Bysted A, Knuthsen P \& Rasmussen S (2007) Effects of red grape skin and seed extraxt supplementation on atherosclerosis in Watanabe heritable hyperlilidemic rabbits. Mol Nutr Food Res 51, 564-571.

87. Rao GN \& Knapka JJ (1987) Contaminant and nutrient concentrations of natural ingredient rat and mouse diet used in chemical toxicology studies. Fund Appl Toxicol 9, 329-338.

88. Saarinen NM, Bingham C, Lorenzetti S, Mortensen A, et al. (2006) Tools to evaluate estrogenic potency of dietary phytoes- trogens: a consensus paper from the EU Thematic Network "Phyohealth" (QLKI-2002-2453). Genes Nutr 3/4, 143-158.

89. Luijten M, Thomsen AR, van den Berg JAH, Wester PW, Verhoef A, Nagelkerke NJD, Adlercreutz H, van Kranen HJ, Piersma AH, Sørensen IK, Rao GN \& van Kreijl CF (2004) Effects of soy-derived isoflavones and a high-fat diet on spontaneous mammary tumor development in Tg.NK (MMTV/cneu) mice. Nutr Cancer 50, 46-54.

90. Naumann E, van Rees AB, Önning G, Öste R, Wydra M \& Mensink RP (2006) Beta-glucan incorporated into a fruit drink effectively lowers serum LDL-cholesterol concentrations. Am J Clin Nutr 83, 601-605.

91. Covas M-I, Nyyssönen K, Poulsen HE, EUROLIVE Study Group, et al. (2006) The effect of polyphenols in olive oil on heart disease risk factors: a randomized trial. Ann Intern Med 145, 333-341.

92. Valentová K, Stejskal D, Bednár P, Vostálová J, Č́íhalík Č, Večerová R, Koukalová D, Kolár M, Reichenbach R, Škňourilová L, Ulrichová J \& Šimánek V (2007) Biosafety, antioxidants status and metabolites in urine after consumption of dried cranberry juice in healthy women: a pilot doubleblind placebo-controlled trial. J Agric Food Chem 55, 3217-3224.

93. John JH, Ziebland S, Yudkin P, Roe LS, Neil H \& Oxford Fruit and Vegetable Study Group (2002) Effects of fruit and vegetable consumption on plasma antioxidant concentrations and blood pressure: a randomised controlled trial. Lancet 359, 1969-1974.

94. Watzl B, Girrbach S \& Roller M (2005) Inulin, oligofructose and immunomodulation. Br J Nutr 93, Suppl. 1, S49-S55.

95. Estruch R, Martinez-Gonzales MA, Corella D, et al. (2006) PREDIMED study investigators. Effects of a Mediterraneanstyle diet on cardiovascular risk factors: a randomized trial. Ann Intern Med 145, 1-111.

96. Beresford SAA, Johnson KC, Ritenbaugh C, et al. (2006) Lowfat dietary pattern and risk of colorectal cancer: the Women's Health Initiative Randomized Controlled Dietary Modification Trial. JAMA 295, 643-654.

97. Baumann KH, Hessel F, Larass I, Müller T, Angerer P, Kielf R \& von Schacky C (1999) Dietary omega-3, omega-6, and omega-9 unsaturated fatty acids and growth factor and cytokine gene expression in unstimulated and stimulated monocytes. A randomized volunteer study. Arterioscler Thromb Vasc Biol 19, 59-66.

98. Mullen A, Moloney F, Nugent AP, Doyle L, Cashman KD \& Roche HM (2007) Conjugated linoleic acid supplementation reduces peripheral blood mononuclear cell interleukin-2 production in healthy middle-aged males. J Nutr Biochem, Mar 16; (Epub ahead of print).

99. Kovar J, Suchanek P, Hubacek JA \& Poledne R (2004) The A-204C polymorphism in the cholesterol 7alpha-hydroxylase (CYP7A1) gene determines the cholesterolemia responsiveness to a high-fat diet. Physiol Res 53, 565-568.

100. Prynne CJ, Mishra GD, O’Connell MA, Muniz G, Laskey MA, Yan L, Prentice A \& Ginty F (2006) Fruit and vegetable intakes and bone mineral status: a cross sectional study in 5 age and sex cohorts. Am J Clin Nutr 83, 1420-1428.

101. Coyne T, Ibiebele TI, Baade PD, Dobson A, McClintock C, Dunn S, Leonard D \& Shaw J (2005) Diabetes mellitus and serum carotenoids: findings of a population-based study in Queensland, Australia. Am J Clin Nutr 82, 685-693.

102. Pavia M, Pileggi C, Nobile CGA \& Angelillo IF (2006) Association between fruit and vegetable consumption and oral cancer: a meta-analysis of observational studies. Am J Clin Nutr 83, 1126-1134. 